\title{
History of Korean Popular Culture: From Its Embryonic Stage to Hallyu (Korean Cultural Wave)
}

\author{
Bok-rae Kim \\ Department of European Culture and Tourism \\ Andong National University \\ South Korea
}

\begin{abstract}
The aim of this paper is to examine the history of Korean popular culture from its embryonic stage to hallyu (Korean cultural wave). The paper is divided into five sections: (1) introduction of mass-media and formation of popular culture during Japanese colonial period (1910-1945), (2) period of war and division from liberation of Korea in 1945 to 1950s, (3) popular culture in period of developmental dictatorship, (4) resistance culture and cultural movement, (5) hallyu as an attractive capital seen from the viewpoint of history of civilizations.
\end{abstract}

Keywords: Korean popular culture, hallyu, mass-media, colonial modernity, cultural imperialism

\section{Introduction}

The history of Korean popular culture begun appearing with the influx of foreign cultures during the opening port era (1882-1910) launched by foreign powers. Thus, it was not built by normal market interaction of supply and demand, but based on "colonial modernity."The concept of colonial modernity cannot be explained by either colonialism or "transplanted" modernity which all happened concurrently in Korean peninsula during the Japanese colonial period (1910-1945). Here, modernity may be equated with industrialization and capitalism. Hence, it is no exaggeration to say that "Japanese popular culture" prepared the ground for Korean popular culture in the beginning period of modern Korea.

The term of "popular culture" was first used in the daily newspaper ChosunIlbo on April 29, 1933, but it seems quite different from what we call "capitalistic popular culture." Popular culture is generally recognized as a "culture enjoyed by a great number of people." If popular culture is focused on cultural appropriation and consumption, another synonym "mass culture" is more emphasized on production process itself. The latter is relatively limited to modern cultural products using mass media, whereas the former has a broader concept of including common people's pre-modern culture. Of course, modern-day popular culture is composed of cultural products producing and distributing by mass media; therefore, two terms are considered "one concept" of viewing the same target in different perspectives. In the Korean discourse on culture, popular culture is thought of as opposite to high culture, folk culture, people's culture and national culture. In comparison to "high culture," popular culture is a mass-produced low-grade culture. In contrast to "folk culture," it is defined as consumer goods commoditized by mass media. In opposition to "people's culture" praised by left-wing student activists in the 1980s, it's an instrumental tool to anesthetize people's consciousness for reproducing establishing capitalistic order. In relation to "national culture," it's a byproduct of Western cultural imperialism. ${ }^{1}$ In sum, the term of popular culture has a "negative" connotation before the advent of hallyu (Korean cultural wave). ${ }^{2}$

It is said that the true sense of Korean popular culture appeared in 1960s where popular culture and mass culture were inseparably fused together. In the process of urbanization (traffic, communication, education and mass media, etc.), it began to develop under the flag of "economic development." More than $50 \%$ of the population lived in rural areas in 1960s, but the rate was completely reversed: from 60\% in urban areas in 1976 into $80 \%$ in 1990s. It's not wrong to equate "urban growth rate" with "popular culture growth rate" in Korea.

\footnotetext{
${ }^{1}$ [in Korean] Popular Culture, Encyclopedia of Korean Culture.Retrieved fromhttp://encykorea.aks.ac.kr/Contents/ Item/E0014804

${ }^{2}$ Hallyu is a neologism literally meaning "flow of Korea." It is the increase in global popularity of South Korean culture since the 1990s.
} 


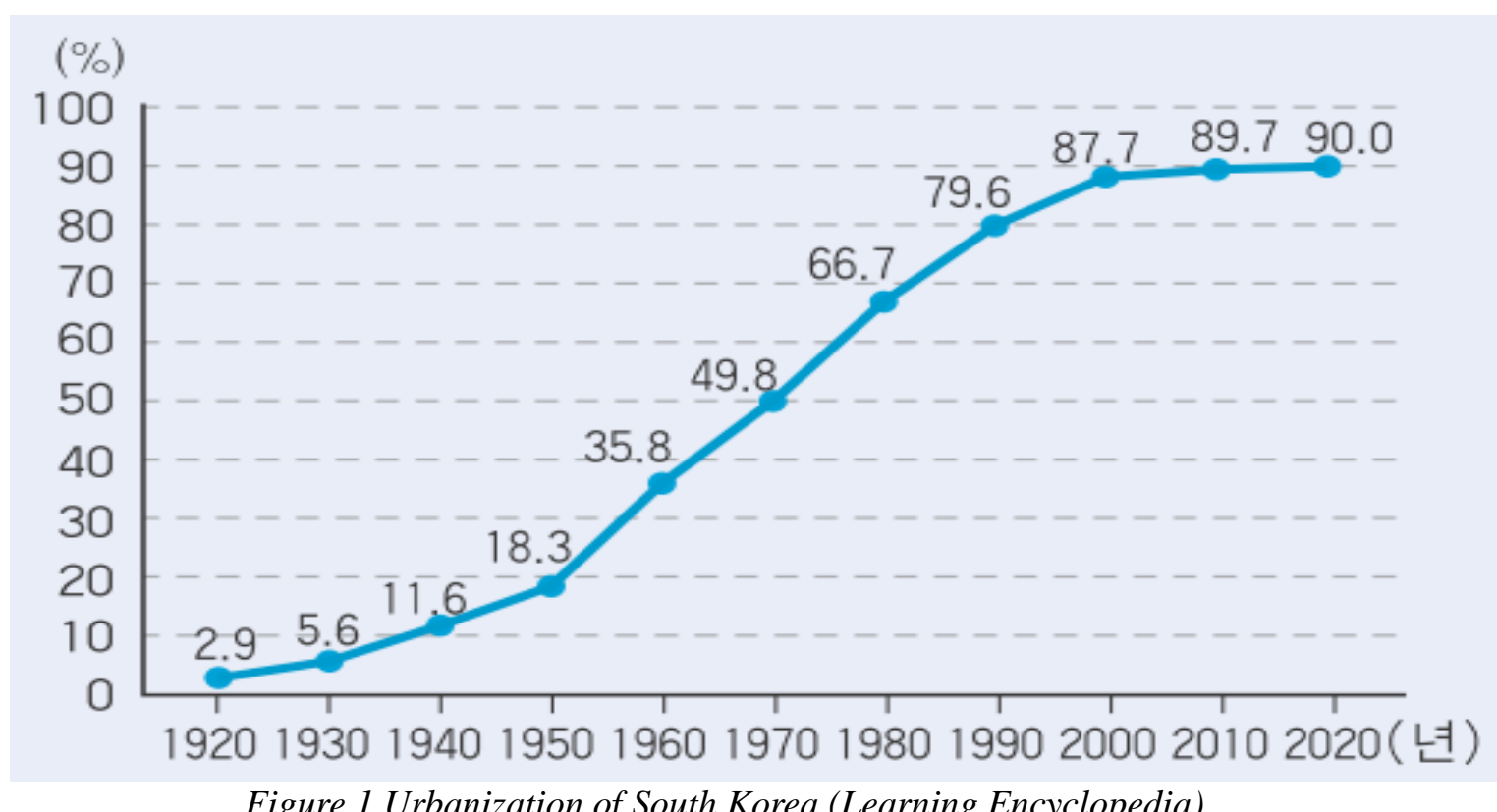

The aim of this paper is to examine the history of Korean popular culture from its embryonic stage to hallyu. The paper is divided into five sections: (1) introduction of massmedia and formation of popular culture during Japanese colonial period (1910-1945), (2) period of war and division from liberation of Korea in 1945 to 1950s, (3) popular culture in period of developmental dictatorship, (4) resistance culture and cultural movement, (5) hallyu as an attractive capital seen from the viewpoint of history of civilizations.

In the 2000s, the researches on Korean popular culture became à la mode and prosperous, thanks to the "modernity" research boom in Korean academic circles. However, an "eclectic" cultural study is not fully discussed among "rightist" and "leftist" scholars in great majority. Unlike the active criticisms and trendy discourses on popular culture as an "attractive capital," our historical research area is very limited. This illustrates that popular culture (antonym of high culture) is not yet recognized as a subject of academic research. This study will bridge a diachronic analysis gap by focusing on the "pen insularity (geo-political particularity)of Korean popular culture" under the historical context using theoretic/analytical tools: cultural coloniality, dependence theory, cultural imperialism, hybridity, consumerism, and history of civilizations, etc.

\section{Introduction of Mass-media and Formation of Popular Culture during Japanese Colonial Period (1910- 1945)}

The history of Korean popular culture started with the influx of foreign - especially "Japanese" - cultures during the open port era (1876-1910). This means that the growth of Korean popular culture was not by logic of free market, but by Japanese colonialism under which Korean people was forced to experience "colonial modernity," in the form of oppression and social control. Of course, the majority of popular culture products was accepted, among Koreans by their "voluntary" needs for cultural consumption. However, all devices, capital expenses and space management for the distribution structure of popular culture seemed "one-sided."

During the Japanese colonial period (1910-1945), modern mass media was introduced into Korea. In the late period of Chosun dynasty (1392-1910), the first modern Korean newspaper called "Hansung-sunbo" appeared on October 1883. When the Japan-Korea Annexation Treaty was signed in 1910, the Governor-General of Korea assumed direct control of the press along with other public institutions. In the 1920s, the history of Korean vernacular newspapers, such as Donga Ilbo and ChosunIlbo, began with the appeasement and cultural policy of colonial government. ${ }^{3}$

\footnotetext{
${ }^{3}$ Following the March 1st Movement in 1919, the colonial government loosened their overt control over cultural activities and permitted several Korean newspapers to function while maintaining some behind-the-scenes direction over politically sensitive topics. 
On the other hand, the history of popular music also started with the beginning of radio station and recording industry. The growth process of Korean popular culture was nothing less than a deluge of foreign cultures, exogenously transplanted into colonial Chosun (old Korea) by way of Japan, by shutting off the possibility of "spontaneous" modernization of traditional culture. According to advocators of "colonial exploitation" theory based on the constant antagonism between imperialist repression and nationalist resistance, it was skillfully used as an ideological tool to facilitate and legitimize Japanese colonial rule over Korean peninsula, under the cloak of modernity.

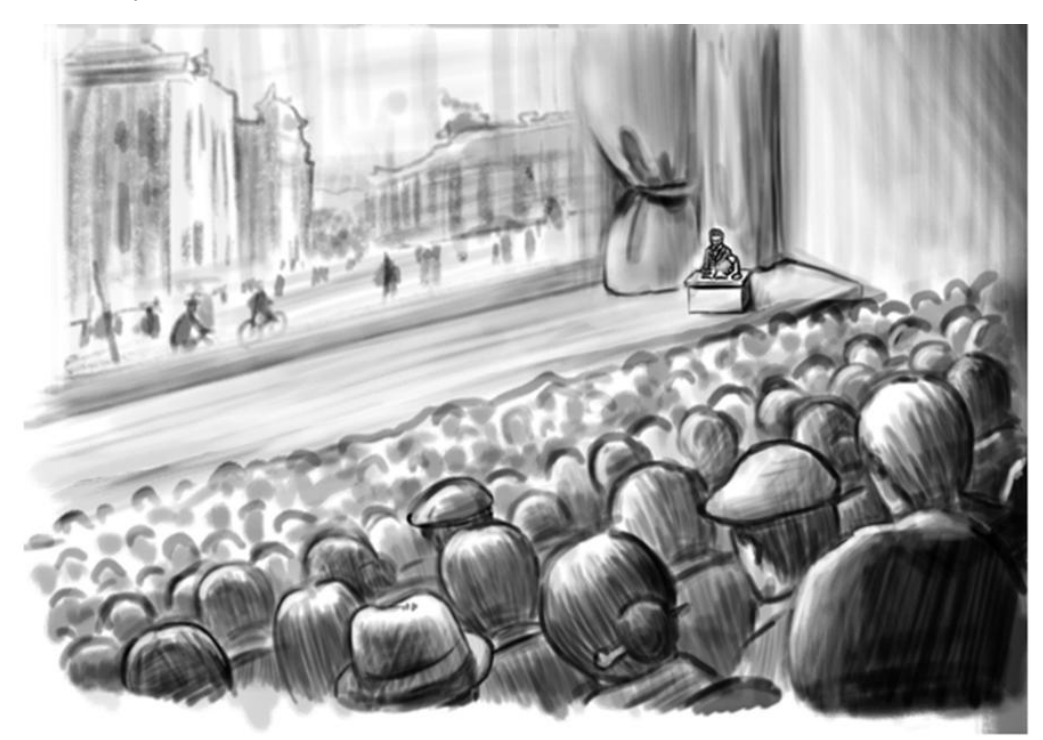

Figure 2 Kino Drama: The «Loyal revenge> showing at Dansungsa Theater.

\section{Movie}

In 1903, a British tobacco company made a promo-motion picture tour to sell cigarettes. So, Korean people encountered the film media for the first time. On October, 27, 1919 , the «Loyal revenge> known as the first Korean domestic film came out as Kino drama, ${ }^{4}$ a live theatrical production against the backdrop of film projected on stage. After 1966, "Korea's Film Day" is celebrated every year on October 27, to mark this landmark. ${ }^{5}$ The movie director Do-san Kim (1891-1921) did not only write a script, but also played the leading role. At that time, there were no actresses, so a male actor dressed up as a woman had to play the role of wicked stepmother (sub-heroine) in this moralistic Kino drama. Kim was a leader of a Shinpa theater troupe. Here, the term "shinpa" as a theatrical phraseology refers to second class or outdated melodramas. In the early twentieth century, however, the term referred to "new wave" as opposed to old-styled theatrical plays. ${ }^{6}$ Shinpa is an old-fashioned word, but it best represents the early trends of Korean popular culture, easily degenerated into "defeatist" self-torture or self-pity in the grim colonial realities. Views on shinpa are divided into positive and negative ratings: some scholars insist that shinpa plays a role as a "bridge" between traditional and realism theaters, whereas others consider it as a Japanese-style commercial melodrama for the sake of arousing interest. ${ }^{7}$

In 1923, a silent movie called<An oath in moonlight> was produced for encouraging savings by the Japanese Government-General of Korea. The first movie in the Korean production was the moralist film <Tale of Two Sisters > in 1924. As an "anti-Japanese" film, the <Arirang > in 1926 became a big hit drawing audiences totaling 150000 people in two years.

\footnotetext{
${ }^{4}$ A play combined with moving picture.

${ }^{5}$ Korean film professionals are pushing to build the public movie museum for celebrating the hundredth anniversary of Korean movie in 2019.

${ }^{6}$ Shinpa is a new genre of play which was popular from the early 1910 to the late $1940 \mathrm{~s}$.

${ }^{7}$ Myong, I.S. (2002). [in Korean] A comparative research on Korean/Japanese shinpas plays with Western melodramas. Journal of Korean Theatre Studies, 18, p. 1.
} 


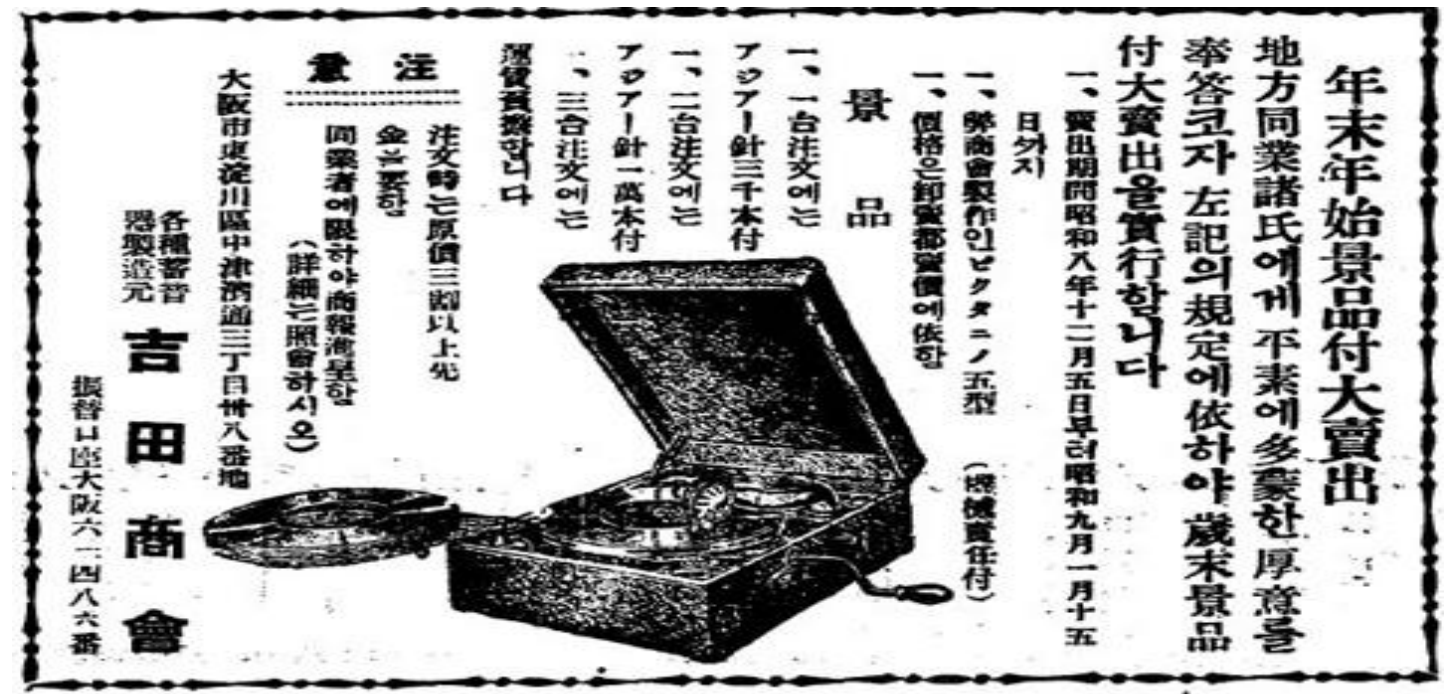

Figure 3 Japanese gramophone company inserted the ad of gramophone in ChosunIlbo, aiming at meeting new demands of Koreans (December 1, 1933)

\section{Popular music}

With the release of 1926's Yun' album "In Praise of Death," the existence of recording was known to public. In general, this song is considered as the beginning of Korean popular music. The number of gramophones increased by about 300000 in the mid-1930s, but high-priced gramophone still was a "pie in the sky" for poor people. For reference, ChosunIlbo (Chosun Daily News) on December 23, 1934, highlighted a bizarre assault case where new invention sparked "popular resistance" before becoming fixtures in everyday life. An old bachelor struck his future mother in law with his fist when the latter broke of his engagement to her daughter, for the reason that he has a gramophone in his house! He bought it as a preparatory step for new marriage life, but the stubborn mother (of the bride) considered it as a "luxury item of a prodigal son" like him. So, he experienced the agony of disengagement against his will..$^{8} 80$ years ago, the gramophone as an early type of record player was considered "the glory of the $20^{\text {th }}$ century" (on July $1^{\text {st }}, 1938$ ), but for a lot of Korean people it was a luxury item with "vulgar and obscene" popular songs. It seems very similar to VCR as a tool to watch erotic adult videos in the 1980s!

In those days, the "trot music" was in vogue. ${ }^{9}$ Like shinpa play, it's a particular genre of Korean popular music, known for its use of repetitive rhythm and vocal inflections, and influenced by many genres of Korean, Japanese, European, and U.S. music. There were two kinds of "sentimentalism" in trot music originated in colonial tragedy: (1) the melancholic sorrows about love and parting between male and female and (2) the feelings of lonely travelers who wander from place to place. On 16 February 1927, Kyongsung Broadcasting Corporation (JODK), former KBS, ${ }^{10}$ was firstly established by the Governor-General of Korea. The organization was founded to develop Korean popular culture and to promote the welfare of Korean people, but (mis-) used for the justification of Japanese rule and political propaganda.

\footnotetext{
${ }^{8}$ Kim, M.W. (2011). [in Korean] The gramophone as a luxury item of a prodigal or hindrance of public order. ChosunIlbo, September 9, 2011. Retrieved from http://news.chosun.com/site/data/html_dir/2011/09/20/2011092002449.html

${ }^{9}$ The name "trot" is a shortened form of "foxtrot," a style of ballroom dance that influenced the simple two-beat rhythm of trot music. Trot and foxtrot do not share any other notable characteristics

${ }^{10}$ Korean Broadcasting System (KBS) is the national public broadcaster of South Korea. It was formerly the Kyongsung Broadcasting Corporation (JODK) 


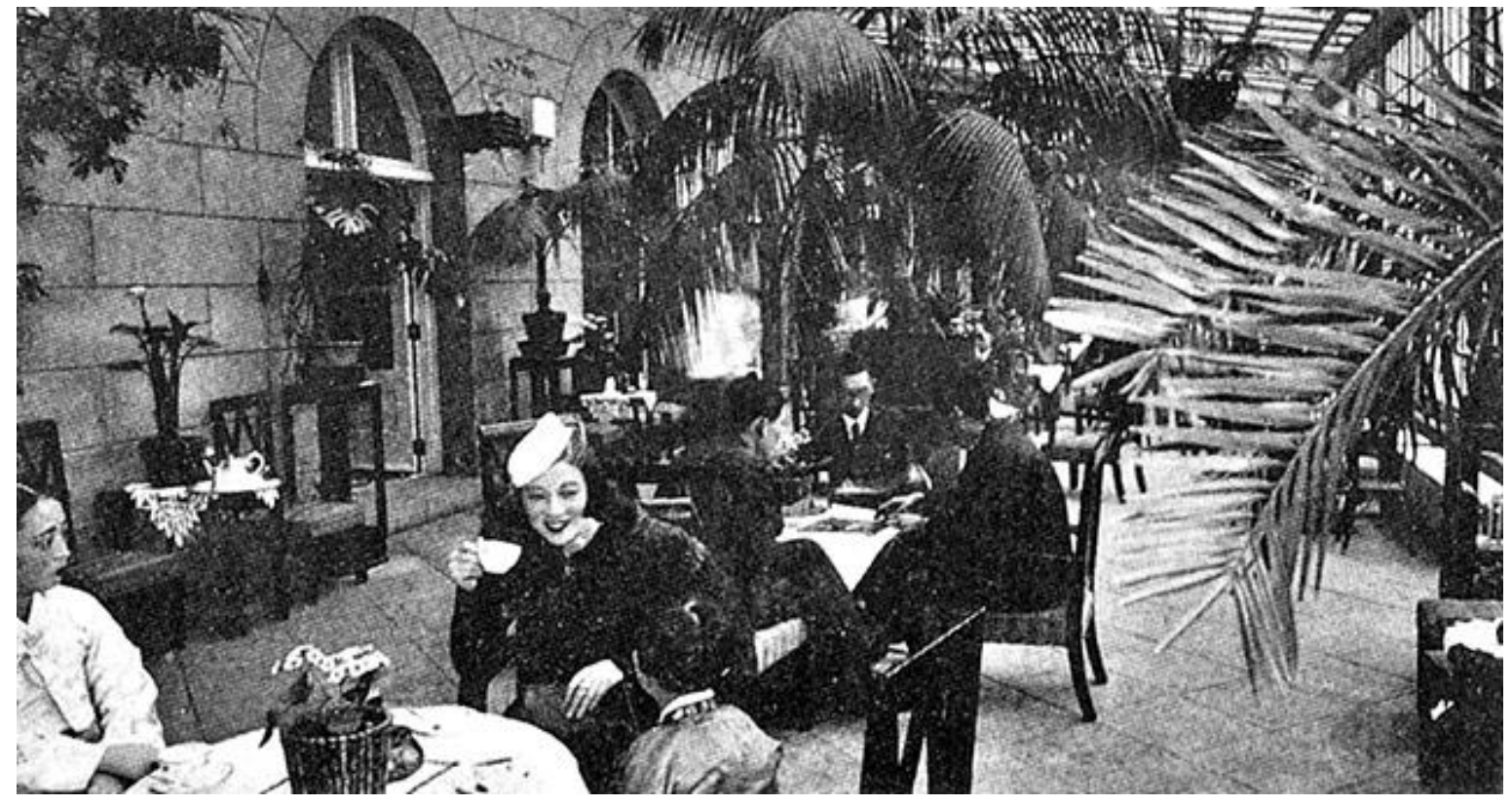

Figure 4 Modern girl in 1930s

\section{Modern boy and modern girl}

Under Japanese imperialism, urbanization was a process of gaining a new industrial base for efficient colonial rule. With the change of landscape in the late 1920s, Seoul was transformed into modern consumer city. As capitalist consumption culture started reorganizing daily living domain, beyond politico-economic ones, modern department stores (symbol of mass consumption) stimulated the public's appetite for consumer goods, despite the structural vulnerability of Korean manufacturing industry at an early stage. With the advent of "modern boys" "and "modern girls" 12 appeared new scenes of urban life where they were sitting in Western-styled restaurants, cafes, tea rooms, theaters, etc.

As symbols of colonial modernity, modern boys and modern girls took the lead in Western-styled urban civilization and consumption culture brought into Korea through Japan. This modern generation as new cultural phenomenon was rapidly integrated into modern-colonial culture in their twofold self-consciousness: fictional longing for Western culture and awareness of wretched life (colonial reality). In recent years, they are no longer considered as decadent individuals trapped in escapism and lethargic conformism, but reinterpreted as new trendsetters expressing their identity through new styles (costume, hair, accessary, language and consciousness).

During Japanese colonial period, censorship, prohibition and seizure of popular cultural products were enforced on a daily basis by the Japanese, but those "repressive" practices were almost unchanged even after liberation. In fact, Japanese popular culture formed the basis of Korean counterpart in its embryonic stage of development. During the period of Japan's invasion of China in the early 1930s and the war that followed, Korean popular culture also received the elements of Chinese popular culture. In other words, Korean popular culture was and still is a "hybridity" as a result of cultural exchanges among China, Japan and Korea, from the outset. ${ }^{13}$

\section{Period of War and Division from Liberation of Korea in 1945 to 1950s,}

The early Korean mass media culture had been heavily influenced by Japanese, but the topography of Korean popular culture was reorganized with the influx of American culture from the 1945 liberation of Korea into US army military government (1945-1948).

\footnotetext{
${ }^{11}$ The modern boy putting on felt hat, necktie and Western-styled clothes became a discourse to refer to new-style male consumers in urban space of Kyungsung (old Seoul) in 1920s.

${ }^{12}$ The term of modern girl with bobbed-hair wearing a short skirt and high heel shoes also refers to Western-styled and/or westernized women in 1920-1930s, with the formation of urban consumption culture in Kyungsung.

${ }^{13}$ Song, D.Y. (2005). [in Korean] Hybridity of Korean Popular Culture: Its Making and Prospect. Retrieved from http://congress.aks.ac.kr/korean/files/2_1358497749.pdf p. 1.
} 
As a result, American popular culture became "mainstream" in liberated Korea, whereas Japanese one lost its former monopoly status. In 1950s, Korean people blindly yearned for America and American culture, as signs of wealth and prosperity. Many new exotic foreign names of Korean popular songs appeared as follows: <Lucky Seoul>, <Lucky Morning>, <San Francisco>,<Youth Avec>, ${ }^{14}$ and <America China Town>, etc. Popular song writers ostentatiously (over-)used English or French words. Through the US army base in Korea, pleasure-seeking American culture was spreading at an alarming rate to meet the psychological needs of Korean masses eagerly wanting to forget the desperate post-war situation.

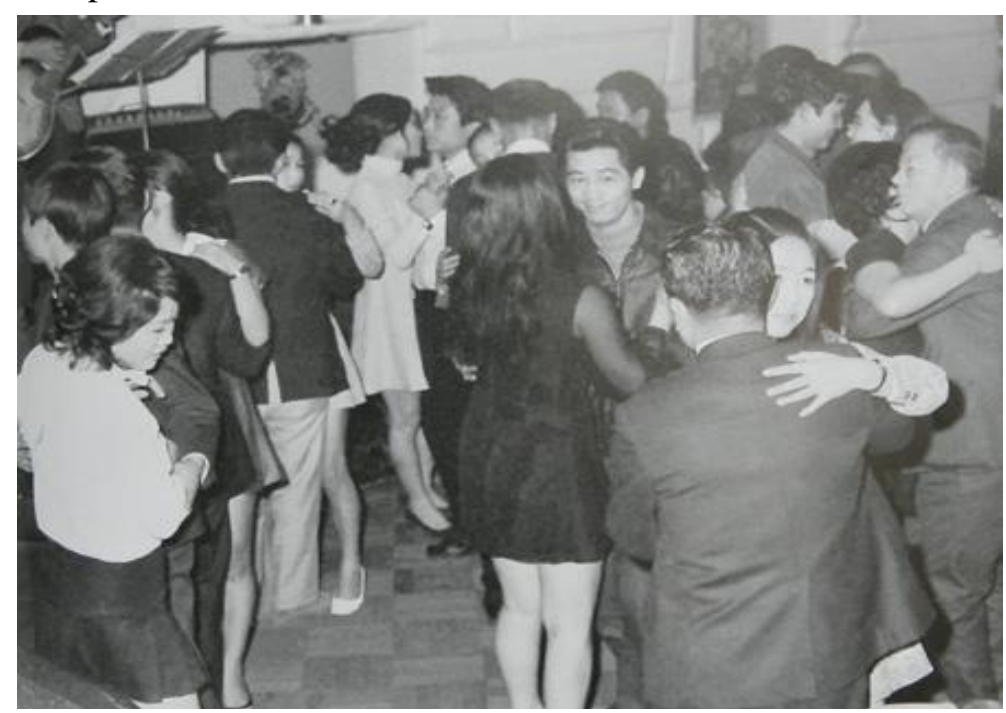

Figure 5 Fever for ballroom dance hall formed a cultural code heating up Korean society from 1950s to 1970s (source of photography: collection of Korean government's documentary photographs)

There was a craze for ballroom dancing, so various dance music prevailed throughout the country, such as $<$ Nilili Mambo>, <Tango of the Rain>, <Singing Cha Cha Cha>. However, all popular songs in 1950s cannot be regarded as having "one directivity" for American culture. ${ }^{15}$ There was a continuity of "hybrid" cultures. After Korean War (1950-1953), Korean people directly and indirectly experienced many foreign countries, including the 16 countries that sent forces to South Korea's rescue under the UN flag. As a result, these kinds of "multicultural" experiences were well reflected in Korean popular culture of the 50s. So, if we equated this process of "enculturation" with that of Americanization, we would be trapped in the schematic frame of cultural imperialism.

After the Korean independence in 1945, the name of a place most frequently appearing in popular songs was "Seoul (capital of Korea)." It can be shown that the importance of Seoul was growing due to the urban development. Following the recapture of Seoul, ${ }^{16}$ Korean people were filled with nostalgias for the past of Seoul. Escaping from Japanese surveillance or danger of war they began to freely admire Seoul. However, this "Seoul in songs" was not a real Seoul, but an ensemble of popular desires for affluence or happiness. In this period of "agony" from the war and the division of the country, the general sentiment of "homesickness" persistently prevailed in Korean popular culture.

On the other hand, it is noticing that Korea faced a crisis of "rupture" of traditional culture which has barely kept its place despite Japanese oppression. To sum up, the acceptance of Western culture resulted in better understanding of international society, but in promoting hedonistic/consumerist material culture while destroying traditional culture. As part of an effort to inherit and restore traditional culture, Korean traditional mask dance and/or samulnori performance (Korean traditional percussion quartet) came into fashion in university towns after 1970s, as a counter-culture of struggle and demonstration.

\section{Popular Culture in the Period of Developmental Dictatorship}

\footnotetext{
${ }^{14}$ The French preposition avec means with and is used to indicate "young couple in romantic relationship" in Korea.

${ }^{15}$ Jang Y.J. (2008). [in Korean] A study on an aspect and the meaning of exoticism of Korean popular songs in the 1950s.Journal of Korean Oral Literature, 27,p. 311.

${ }^{16}$ The five battles of the Korean War fought in and around the city of Seoul are known as the Battle of Seoul. 


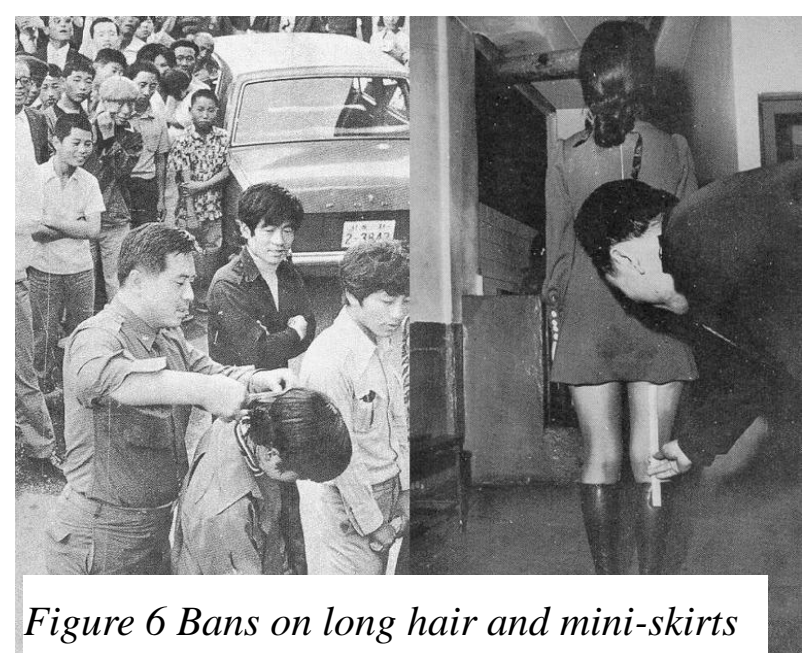

\section{Park's government}

After May 16 coup, ${ }^{17}$ the Chung-hee Park Government (1963-1979) ${ }^{18}$ began to reorganize mass media as a tool for promoting his regime's legitimacy, national unity as a whole, anti-communism and modernization. In 1960s, the "new era of mass media" was heralded with, state-run and private-run radios and TVs, etc. ${ }^{19}$ As the "export-led high growth" policies propelled by Park's leadership obtained good results in the early 1960s, Korea has rapidly taken on the main characteristics of mass society since 1970s. The foundation of "commoditized" popular culture was established by mass media, rural exodus and urban concentration providing consumption spaces. This marked the beginning of "color TV age," as a product of cold war \& anti-communism, a symbol of modern culture, and a medium to construct "thick" semantic networks in daily life.

Table 1: TV Penetration rate: from luxury good to daily necessity good in $1970 \mathrm{~s}^{20}$

\begin{tabular}{|l|l|l|}
\hline Year & $\begin{array}{l}\text { Number of TV sets } \\
\text { in use }\end{array}$ & $\begin{array}{l}\text { TV penetration rate per } \\
\text { household }(\%)\end{array}$ \\
\hline 1970 & 379564 & 6.3 \\
\hline 1971 & 616392 & 10.1 \\
\hline 1972 & 905363 & 14.3 \\
\hline 1973 & 1282122 & 19.9 \\
\hline 1974 & 1618617 & 24.2 \\
\hline 1975 & 2061072 & 30.3 \\
\hline 1976 & 2809131 & 41.1 \\
\hline 1977 & 3804535 & 54.3 \\
\hline 1978 & 5135496 & 70.7 \\
\hline 1979 & 5967952 & 79.1 \\
\hline
\end{tabular}

Whenever we consider the popular culture at the height of Park's regime, scandalous marijuana case ${ }^{21}$ bans on long hair and mini-skirts, and "forbidden songs" come to mind. In any case, it seems almost impossible to comprehend its nature without any reference to cultural controls (for example, linkage of best movie selection to import right of foreign movies). For the promotion of domestic films and the "purification" of entertainment films against public morals, Park's government gave an "award" to import lucrative foreign movies to Korean movies selected as being "good and sound, "regardless of their box office hit or failure. These good movies were implicitly assumed to meet the government needs: therefore, this rewarding system (or censorship) resulted in relative quality degradation and depression of Korean film industry. However, can we judge various genres of popular culture in1970s, by two schematic codes "oppression" and "resistance?"This question is closely related to the heated controversy on the identity of "youth" culture in those days.

\footnotetext{
${ }^{17}$ The May 16 coup was a military coup d'état in South Korea in 1961, organized and carried out by Park Chung-hee (19171979) and his allies who formed the Military Revolutionary Committee.

${ }^{18}$ Chung-hee Park (1917-1979) was a South Korean politician and general who served as the President of South Korea from 1963 until his assassination in 1979, assuming that office after first ruling the country as head of a military junta installed by the May 16 coup in 1961.

${ }^{19}$ The first TV commenced in the form of American commercial TV station in Korea in 1956 by the Syng-man Rhee government (1948-1960).

${ }^{20}$ Jung, S.I, \& Jang, H. S. (2000). [in Korean] 40 years of TV history: Social history of TV program. Seoul: Hanwool Academy, p. 119.

${ }^{21}$ Over 50 entertainers were arrested for smoking marijuana in 1975. In the 1970s, amid its associations with insurgent youth culture abroad, cannabis was banned under the Cannabis Control Act of 1976
} 
In the column "Fashion or Rebellion?" of Shin Dong-A magazine (July, 1974), ${ }^{22}$ Prof. Jae-bong Rho maintained that the youth popular culture originated in night clubs and bars was an "out let" for young people to excrete their pains. As a conservative commentator, he called it a "counter-culture," as a passing fad. According to him, almost all countercultural heroes were nothing but hippies!

On the other hand, leftist intellectuals also criticized the Westernized youth culture, as an "alien" culture with unidentified identities. The youth culture blooming in university towns was represented by three key words: acoustic guitar, blue jeans and draft beer. Even though young people claimed to stand for the following catchphrases "resistance, romance and youth," it was a byproduct of Westernized/Americanized consumer culture largely influenced by logic of capitalism, according to leftist intellectuals. For reference, the blue jean was closely related to the mass supply of most exported clothing goods. The vogue of draft beer was also due to the fierce competition of beer companies which have changed their sales strategy from bottled beers to draft ones. Furthermore, some dissidents insisted that anachronistic "Datsu-A Ron" has been an inherent part of Korean youth culture of 1970s. ${ }^{23}$ The gist of Japanese-styled Datsu-A Ron is to emulate Western culture, so that West may not equate Japan with Chosun (old Korea) and China to ultimately win Western imperialism.

The "1970s" was for government the era of "modernization of the fatherland" (Yushin modernization with "compressed" growth) $;{ }^{24}$ for student activists and leftist intellectuals, the era of restoration of people's democracy; and for ordinary people, the era of mass culture. Contrary to the criticism of rightist and leftist camps, young people neither blindly adopted foreign popular culture, nor were immersed in low-grade cultural products. They actively participated in consuming radio and TV cultures by and for making their own identity, as "autonomous" cultural subjects. In 1970 s, the college entrance rate was merely $8.4 \%$, but in 1980s it increased by $15.9 \%$ (almost a twofold increase). These academic careers\& cultural capitals permitted "freewheeling" young people to be differentiated from their father generation. Neither conservative adults nor self-justified "democratic combatants"

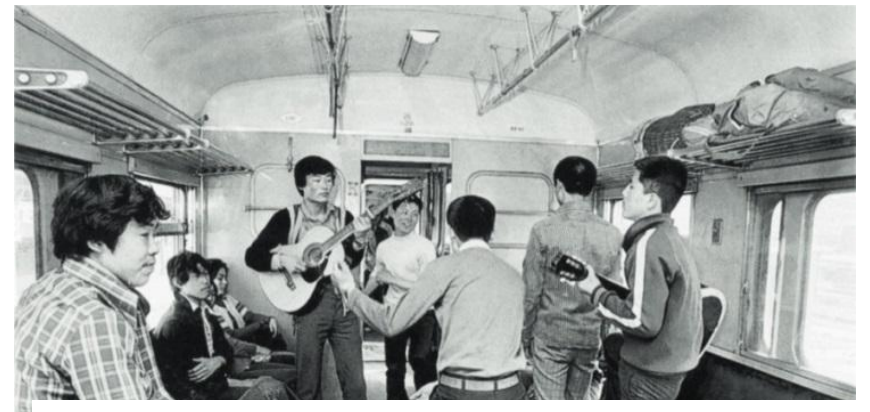

Figure 7Young people singing, dancing and playing guitar loudly in suburb train in 1970s

(against dictatorship), but ordinary college students simultaneously played the role of consumer \& producer, for the first time in the history of Korean popular culture. This formation of youth culture provided a springboard for future "hallyu" represented by new generation or young K-pop idols. ${ }^{25}$

\section{The Fifth Republic}

During the period of the Fifth Republic (1981-1988), the government frequently held large-scale cultural events to promote its legitimacy of power. This period saw many mega-events such as Guk-poong $81,{ }^{26}$ Miss Universe, 1986 Asian Games and 1988 Olympic Games. As a representative example of "obscurant" policy during the Doo-whan Chun government (1981-1988), ${ }^{27}$ leftist intellectuals and activists are very fond of enumerating the socalled“3 S policies" (screen, sports and sex).

\footnotetext{
${ }^{22}$ Oh, G. H. (1974). Fashion or rebellion?Shin Dong-A magazine, on July 1974. .

23"Datsu-A Ron" (脱亜論) was an editorial published in the Japanese newspaper JijiShimpo on March 16, 1885 arguing that Meiji Japan should abandon the conservative governments of Qing China and ChosunKorea and align itself with the West. The title "Datsu-A Ron" has been translated in a variety of ways, including "Good-bye Asia," "De-Asianization,"“Shedding Asia" and "Leaving Asia.".

${ }^{24}$ From 1972 to 1979 , power was monopolized by Chung Hee Park and his Democratic Republican Party under the highly centralized authoritarian "Yushin System."The term Yushin in Korean means "rejuvenation" or "renewal," it has the same Chinese root of "restoration" as component of the Japanese Meiji-ishin, meaning Meiji Restoration.

${ }^{25}$ Kim, J. S. (2013). [in Korean] A Study on Korean youth culture in 1970s as cultural producers. Journal of Korean Studies, 2, Retrieved from http://cks.pccu.edu.tw/ezfiles/213/1213/img/1237/11.pdf, pp. 167-169.

${ }^{26}$ The Korean word "guk-poong" literally means "national wind." Guk-poong 81 was a retro-trend cultural event designed to lay dissident and resistant cultures under the government control.

${ }^{27}$ Chun Doo-hwan (1931-) is a South Korean politician and former South Korean army general who served as the President of South Korea from 1979 to 1988, ruling as an unelected coup leader from December 1979 to September 1980 and as elected president from 1980 to 1988.
} 
Chun's government enforced to neutralize anti-governmental political issues by adopting economic growth as the nation's foremost ideology and/or by turning people's interest into sports or hedonistic entertainment industries. In the 1980s, the popular culture was divided into formal (institutional) and informal (non-institutional) areas which were opposed sharply.

Under Chun's regime, the Broadcasting Ethics Commission became "statutory," with the establishment of the deliberate room carrying out obligatory "preliminary review." The aim of regulating popular culture was to reproduce authoritarian ideas (peaceful reunification of two Koreas and naturalization of Korean-styled democracy), and to expel unhealthy and decadent popular culture. However, the excessive practice of censorship ended in reversely inflating people's desire for the violent and sexually suggestive contents on TV program and led to a reduction in quality of popular culture itself. During the Fifth Republic period, some leftist intellectuals were engaged in the publication of Mook (magazine + book), ${ }^{28}$ by the enforcement of control policy on periodicals (cf. revocation of registration). The mooks were in fashion in the late 1990s and the early 2000s, but recently declined because of internet development.

Aside from censorship policy, unrelated legal devices (national security law and assembly law) were also mobilized to control cultural activities. According to left-wing scholars, it shows an aspect of oppressive "patriarchal" society. They insist that there are double standards and two-facedness: hedonism and rigorism in Chun's cultural policy. Hedonism is needed to maintain the monopolistic capitalism under the auspices of military government, as a means to block people's conscientization. On the other hand, rigorism is also necessary to achieve the efficient economic growth and state mobilization against labor force. This analysis seems very simple and too much dogmatic on Marxist basis.

\section{Under the Sixth Republic (1988- to the present)}

Under the Tae-woo Roh government (1988-1993), ${ }^{29}$ Korean popular culture was transformed into "softwareoriented" from previous hardware-oriented culture. If the cultural policy of Chun's government is focused on the construction of large-scale cultural institutions and the promotion of local culture, that of Roh's government pursues a differentiation by developing policy programs of "cultural contents." ${ }^{30}$ In 1990, Minister of Culture and Public Information created a new ministry of culture, and established 10-year cultural development plan under the goal of "cultural democracy."The "regulation" - a main issue in the governments of Park and Chun - was starting to slacken off, in accordance with the enhancement of people's consciousness and the development of consumptive culture industry. Korean popular culture tended to be "de-politicized" and more hedonistic. With the acceleration of capitalism, Korean people were also aware of their consumer desire as mass consumers.

\section{Resistance Culture and Cultural Movement}

Left-wing intellectuals consider the 1960-70s as an expansion period of "taxidermied" government-control culture and commercial mass culture. ${ }^{31}$ They conclude that the cultural policy in 1960-70s was used as a means of promotion \& education to stay in long-term power, and to mobilize the public. They regard it as a process of monopolizing public memory or dominant ideology by dictatorship.

In resistance to this depraved mass culture playing a role of its "handmaiden of power," renewed/reactionary people's culture - in art, theater, and literature - started to form an important pillar of leftist social movement: (1) revival movement of traditional culture in 1960s, (2) folk art performance and arts of "protest" in 1970s, (3) people's cultural movement in 1980s.

\footnotetext{
${ }^{28}$ The mook is a neologism (magazine + book). It can be easily read like magazine including the latest information, but published in the form of a book like "magabook" or "bookazine" in US.

${ }^{29}$ Tae-wooRoh (1932-) is a former South Korean politician and ROK Army general who served as President of South Korea from 1988 to1993.

${ }^{30}$ CCI (cultural contents industry) is a term widely used in Korea and also referred to as the "cultural industry," "contents industry" or "media \& entertainment industry."

${ }^{31}$ Jung, I.D. (1985). [in Korean] Essay on cultural movement, Theory of cultural movement, Community 4. Seoul: Community, p. 19.
} 
People's culture in "retro style" had its earliest beginning in the 1970s, with the advent of industrialization. In the mid-1960s, there were active study groups on Korean mask dance at colleges, busy themselves in searching for the "authentic" roots of Korean traditional culture and outdoor performances by denying uncritical acceptance of foreign (Japanese/American) cultures. Here, people's culture means a "resistance" culture of "subjugated" people. It was created of the people, by the people, for the people, with their own idealized version of the independent, virtuous, hard-working farmers and laborers groaning under the weight of oppression. In 1980s, people's cultural movement was adopted by so-called "progressive" student activists interested in the modernization of traditional culture. The "discovery of people (imagined community)" was the main cultural code making them involved in fierce protests in the 1980s. The emphasis on pivotal role of "labor class" was the key feature of social movement of the $80 \mathrm{~s}$ led by those radical student activists. Due to censorship and political oppression, the proponents of resistant culture were obliged to make illegal/separate structure of production \& distribution of people's culture, out of established mass culture. There is a cultural dichotomy, according to ideological schemas.

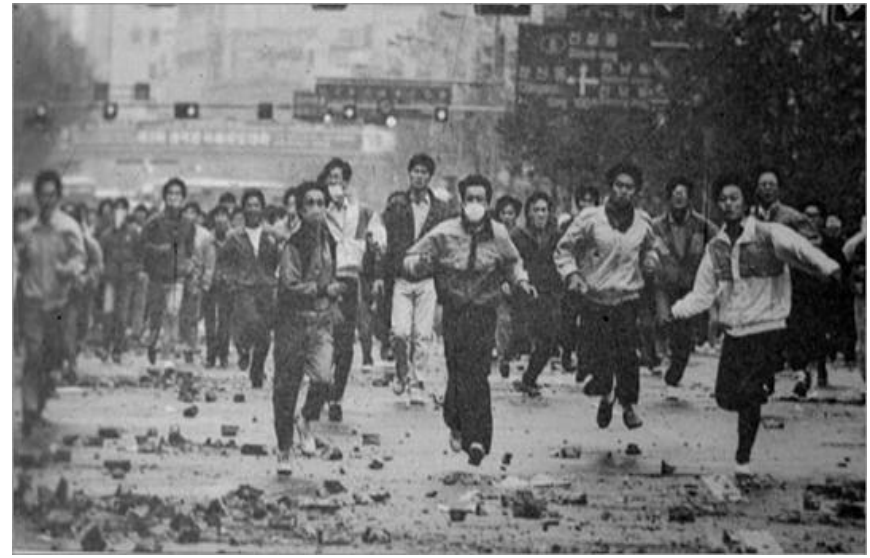

Figure 8 Student activists' protest in the 80 s
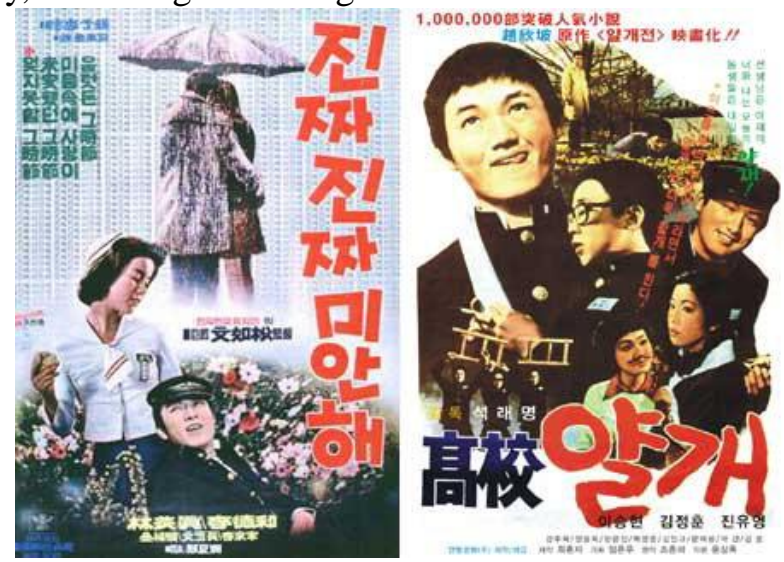

Figure 9Korean teen/high school romance films in 1970s

Table 2: Mass Culture and People's Culture

\begin{tabular}{|l|l|l|l|l|l|l|}
\hline $\begin{array}{l}\text { People's } \\
\text { culture }\end{array}$ & $\begin{array}{l}\text { Autonomous } \\
\text { people }\end{array}$ & Resistance & Nationalism & $\begin{array}{l}\text { Non- } \\
\text { institutionalized }\end{array}$ & $\begin{array}{l}\text { Micro- } \\
\text { media }\end{array}$ & Illegal \\
\hline $\begin{array}{l}\text { Mass } \\
\text { culture }\end{array}$ & $\begin{array}{l}\text { Non- } \\
\text { autonomous } \\
\text { people }\end{array}$ & Domination & Imperialism & Institutionalized & $\begin{array}{l}\text { Mass- } \\
\text { media }\end{array}$ & Legal \\
\hline
\end{tabular}

From 1960s to 1980s, Korean popular culture was mainly focused on deliberately encouraging people to escape from politics. The resistance to dictatorship resided in the people's culture in university towns, but the latter almost disappeared into the mists of history, due to democracy and economic growth. In the late 1970s, Korean "teenagers" (not student activists) started to wield strong influence over popular music. Nowadays, teenagers are the main purchasing group in Korean popular culture market. It is well known that they have hit the mainstream since 1990s, but it was in 1970s that they began to grab the attention of the media as significant consumers, through the boom of Korean teen/high school romance films. ${ }^{32}$

\section{Hallyu as an Attractive Capital seen from the Viewpoint of History of Civilizations.}

From 1960s to the present, one major trend in Korean popular culture is to import and imitate American and Japanese cultures. Because South Korea imported TV hardware and its software products, Korean broadcasters couldn't systematically concern themselves with creative TV program formats in those days. They were merely content with imported ready-made program formats by injecting some "Korean elements" into them.

\footnotetext{
${ }^{32}$ According to left-wing analysis, the "troublesome" youth culture is absolutely mainstream in current popular culture, but in the order of social discourse these teens are still seen as non-mainstreamers or even as objects of oppression, because their parent groups seize the power in social hierarchy. 
However, Korean popular culture has improving and strengthening its "competitiveness" by establishing its own refined style, being freed from imitating Western and Japanese cultures in 198090s.

Hallyu (Korean Wave), as the "transnational flows" of Korean popular culture since 1990s, is composed of (1) competitive cultural contents, (2) attractive stars capable of reproducing "fandoms" on an enlarged scale, and (3) mass media promoting and sustaining cultural consumption in symbiotic relationship. It is said to be a result of "fortuitous happenstance" that no one would possibly have imagined before. ${ }^{33}$ Now, it's a "state

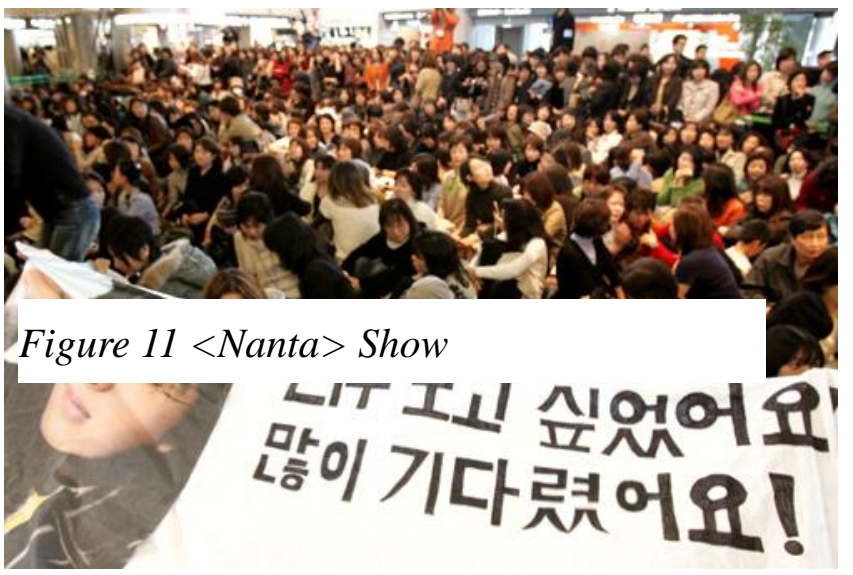
undertaking" that Korean government, business men, and prominent cultural figures combine their effort to

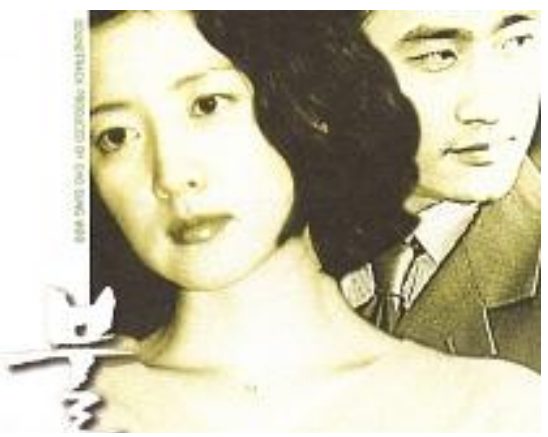

Figure 10 Korean SBS TV drama <Flame> (2000)

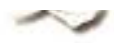
succeed, along with nationalism. Many believe that hallyu has succeeded in demonstrating the "superiority" of Korean people/nation all over the world. Is that true?

From the nationalistic point of view, the boom of hallyu is owing to the "excellence" of Korean popular culture, because uncompetitive cultural products cannot be sold in foreign market. However, is a Cinderella-like success story of hallyu possible, only with its own competitive power? Of course, the success of hallyu is intertwined with global, regional and national elements. Despite the growth of Asian media markets, there are few Asian countries capable of producing attractive cultural products. It's no exaggeration to say that there was no "transnational" Asian popular culture in the early and mid-1990s, except Hong Kong movies and Japanese popular culture (TV drama, animation and music).For reference, the influence of Japanese popular culture was, as strong as that of American one, in some Asian countries in 1990s. Nonetheless, in late 1990s it has progressively languished: on account of(1) repetitive "similar patterns" of Japanese cultural products with which contemporary Asian consumers always trying something new are fed up; of (2)"high prices"; and of (3)restrict and complex Japanese intellectual property rights being burdensome for foreign importers. Korean TV dramas were introduced in Taiwan where Japanese culture was very familiar and generalized in the early 1990s, but they were not well received. However, after a smash hit of Korean drama <Flame> (2000), Korean TV dramas started to captivate Taiwanese with high viewer ratings. Taiwan or Hong Kong, as a mecca of fashion, can be a "test market" in greater Chinese region. Thus, the fever of hallyu in Taiwan has a riffle effect on other Southeast Asian countries.

From a point of view of "civilization history," hallyu is a novelty. If Hollywood culture is a dominant culture, hallyu is an "emerge" culture. In Asia, there are two dominant cultures: (1) Sino centrism which has been strong for thousands of years in Chinese character (Hanzi) cultural sphere, and (2) Japanese modern industrialism. Both have an "imperialistic" nature from the beginning. If Chinese culture is a gro-pastoral, Japanese culture is modern-industrial one being made by adopting Western culture. On the other hand, a "new third-wave culture" emerges in information-oriented society of the $21^{\text {st }}$ century. It's hallyu that is spreading into China, Japan and Southeast Asia, and so on. The advent of post modernhallyu implies the end of premodern Sinocentrism and modern Japanese industrialism. Hallyu can go ahead, on the basis of information society's new paradigm with highly networked technology. According to Korean cultural critic O-youngLee (1934- ), networking information society is least likely to be collapsed by external stimulus.

\footnotetext{
33 This cultural phenomenon has been closely connected with multi-layered "transnational" movements of people, information and capital flows in East Asia.
} 


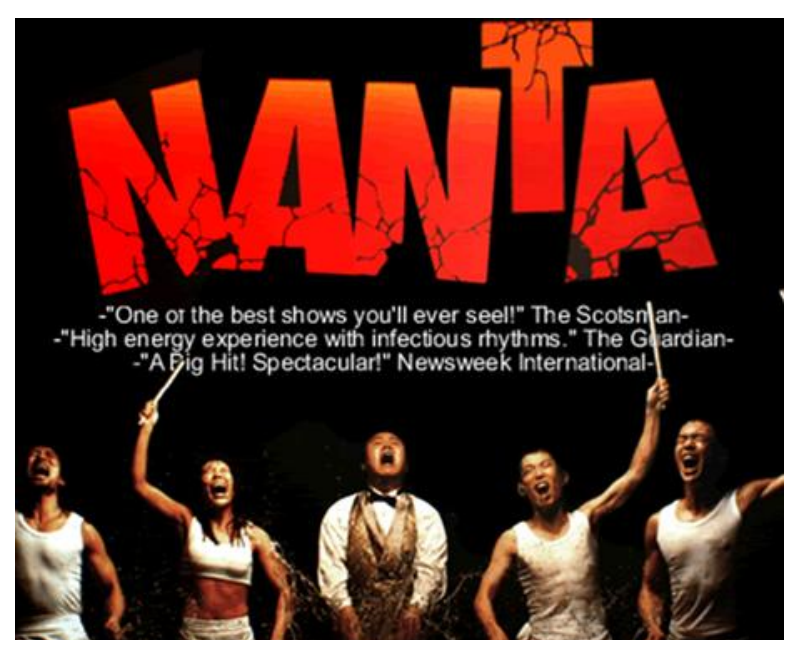

Figure 12 Yon-samasyndrome in Japan

For example, Walt Disney Company - superlative cultural infra in industrial society - can be heavily bombarded by external attacks, but you never catch "Mickey Mouse" with a mousetrap. ${ }^{34}$ Indeed, it's a power of (postmodern) cultural contents. By the same logic, the popularity of $<$ Winter Sonata> (produced by Korean channel KBS2 in $2002)^{35}$ and the syndrome of Yon-sama (Emperor Yon) ${ }^{36}$ cannot be built by Chinese military power or Japanese economic power. Hallyu is not an industrial infra, but a matter of the heart; that is, a matter of culture. In industrial society, national wealth is decided by GNP, but in information society it's by NCP (National cultural productivity) or CI (Creative Index). Korea is ranked No. 1 in NCP or CI in Asia, as the "enfant cheri" in mass media of the $21^{\text {st }}$ century (mobile phone, CDMA, ${ }^{37}$ high-speed internet). In industrial society, a scale economy is a key to success, but in information society "scope" economy makes or mars. Ultimately, "one source multi use" is the most competitive power, and hallyu is the paragon of this one source multi use!

Korean adjective "utbisut" means "same but different." For example, our Korean mindset to regard Christianity and Buddhism as "same and different" is well melted into this one word, as a symbol of Korean-styled "receptivity" or "embracement." In Korean culture playing a role as a "bridge" between Chinese continental culture and Japanese marine culture, there are various values embracing the "multiculturalism" of the $21^{\text {st }}$ century. In relation to the enthusiasm for hallyu stars, we can say that human isa high value-added commodity. The attractiveness of hallyu is in K-pops and movies, but especially converged on hallyu stars. Korean hallyu starsseem to be "attractive agents" capable of realizing a dream in The Dream Society by Rolf Jensen (1999). Asian fans can get vicarious satisfaction, from hot and cool, and dynamic Korean stars.

For example, the "ecstasy" in the $<$ Nanta $>$ show $^{38}$ is both its strength and also weakness of hallyu. A fan, or fanatic is a person who is enthusiastically devoted to something or somebody, such as a singer or band, a sports team, a genre, a politician, a book, a movie or an entertainer. Hallyu is a culture of fans, namely that of irrational enthusiasm. A pessimistic view on hallyu as a passing fad is derived from this "fanaticism" inherent in hallyu itself. However, being rational or theoretical is a product of industrialism, and the 21 st century's culture is fanatic! Koreans have special talent. They are very good at the song and dance from ancient times. They are not conquerors who become rich by suppressing "others" or stripping money from them, but peaceful people who please their neighbors by singing and dancing. Do you know the story of <The Ants and Grasshopper> in Aesop's Fables? As a new paradigm of the $21^{\text {st }}$ century, this spirit of "anthopper" is really needed in future-oriented Korean society. Here, the anthopper is a compound word: grasshopper (leisure) and ant (labor). ${ }^{39}$

\section{Conclusion: Equation for Success}

Popular culture is said to be a "collection of optimal data and texts" showing the history of an epochfull of ups and downs. It's not only a product of society, but also an expression of life experience \& consciousness common to the average members of a society.

\footnotetext{
${ }^{34}$ Lee, O.Y. (2006). [in Korean] Power of Anthopper! Blue Ocean of hallyu continues. JoongAng Monthly. Retrieved from https://jmagazine.joins.com/monthly/view/245626

${ }^{35}$ A melodrama about first love, lost memory and unknown family ties, <Winter Sonata> became an unprecedented success in Asia and more than 20 countries, particularly in Japan.

${ }^{36}$ Yon-sama is ahonorific nickname of the hero Bae "Yong"-joon in the Korean TV drama < Winter Sonata>.

${ }^{37}$ Code Division Multiple Access.

${ }^{38}$ Nanta, also known as Cookin or Cookin' Nanta, is a South Korean non-verbal comedy show created and produced by Seung-whan Song and incorporates traditional "samulnori" rhythm. Samulnori is a genre of percussion music originating in Korea. The word samul means "four objects" and nori means "play"; Samulnori is performed with four traditional Korean musical instruments. Is

${ }^{39}$ Lee, op.cit., pp. 1-5. 
Popular culture is not entirely equivalent to media culture, but the development of Korean popular culture has heavily relied on mass media. Before hallyu, "internationalization" of Korean popular culture in other words, Korean popular culture - since its birth in 1960s - tended to receive "negative" reviews from right and left-wing critics, as "low" culture, as contrasted with the elite or high culture.

In my opinion, an epistemological debate on the identity of hallyu: vulgar "commercial product" or pure "cultural phenomenon" among Korean scholars seems overly speculative, as of today where the border between high and popular culture is ambiguous. According to left-wing Prof. Won-dam Paik, hallyu is a "small store" that we Koreans could open with great difficulty in the global market, through the vertical mobility from the periphery into "demi-periphery" and by the logic of exclusion and exploitation (by enduring history's ordeal - colonialism, division of two Korea and long years of "crippled" capitals). Furthermore, she argues that, for Japanese, hallyu signifies a sophisticated consumption of "nostalgia" for the past by a people kicked out of cultural center to periphery in a "closed circuit" of Japanese society. For Chinese and South-East Asians, it's a "transcendental" experience for the foreseeable future. It's a sarcastic view on hallyu as a bastard of capitalism (or developmental dictatorship). On the other hand, a Korean sociologist Hyun-mee Kim joins in this socialist-led debate by analyzing hallyu as the "synchronism of desires" in Asia. Hallyu, as cheap goods, is not thanks to Korean popular culture's qualified excellence and cultural peculiarity (Koreanness), but its capacity to beautifully package the most worldly, materialistic, and capitalistic desires that hide various conflicts (gender identity, intergenerational miscommunication) inherent in Asian society experiencing rapid industrial capitalism in oppressive/standardized ways like Korean case. According to left-wing camps, there is a coherent tendency to emphasize strong points of hallyu (excellence of Korean culture or positive economic effects) in Korean discourse on hallyu, but negative sides exist like the back of sunny side. For example, the reaction to the fever of hallyu- such as "anti-hallyu"or aversive-hally $u$ current in China/Japan-can have negative effects on Korea's national image. Moreover, the socalled "cultural imperialism" is hidden under the shadow of hallyu. The cultural imperialism is a dominantsubordinate relationship between highly developed capitalist and under-developed countries. Is halllyu culturally imperialistic? According to left-wing camp, American popular culture represents "Great America" as an axis of American capitalist ideology. But the problem is American culture has been uncritically absorbed, like a sponge, into Korean cultural topography since Korean War. This "hybridity" of American culture in Korea has the merit of creating/developing new culture, but the demerit of being in the "advance guard of cultural imperialism."However, the theory of cultural imperialism is facing mounting criticisms from many quarters, and the rapid growth of Korean economy forms a basis against the "dependence theory."Nowadays, we can distinguish neither "our own" from western things, nor an original from an imitation. Thus, the stereotyped binary periodization "western imperialism vs. colonialism" and/or "the First World vs. the Third World," hardly stands any longer.

Therefore, the success of hallyu can be viewed according to an economic theory of "comparative advantage" from highly competitive into low-competitive countries, as water flows from top to bottom. If international trade environment or competitive edge is changed, the position of importer and exporter can be reversed at anytime.

It wasn't a coincidence that the birth of hallyu was right after the national financial crisis in 1997-98. In fact, the Korean pop music industry was in long-term structural decline, due to the IMF cold wave and digitalization. Primarily because of the limit of home market in saturation, they had to make headway into the overseas market. As a desperate self-rescue measure, they succeeded in producing a "golden goose" called "hallyu," through digitalization and Asianization/globalization.

As viewed in the people's culture in 1970-80s, all capitalistic/materialistic desires are not always honorable and self-justifiable. However, there is no shame, if we ruminate on our modern history of hardship. Koreans fiercely compete to survive with the following as their life philosophy: "export or perish," on account of a high level of Korean dependence on exports. According to Korean old proverb, "I feel a pain in my stomach, whenever my cousin buys a land!" It means an envious man grows lean with the fatness of his neighbor. This will-powered entrepreneurship is highlighted as a prime mover to achieve the "miracle of Han River" from the ashes of the Korean War in 1950-53.

Not all countries can succeed in exports of popular culture in world system. So, it is necessary to complement these above "macroscopic" views by following mid-scopic and microscopic views. According to Secret of the Korean Wave (Hallyu), ${ }^{40}$ the success factor of hallyu is in the DNA of hallyu we Koreans never knew existed.

\footnotetext{
${ }^{40}$ Yoo, S. C, et al.(2005).Secret of the Korean Wave. Seoul, Korea: Thinking Tree. .
} 
Koreans usually like to talk, to meddle in other people's affairs, and to shout "palipali (hurry up or faster)" in daily life. This national character of high-tempered Koreans is great advantages (not disadvantages) for the growth of Korean popular culture. This Korean DNA energy can be divided into three kinds: universal energy ( $g i)$, intrinsic joy (heung) and care and affection (jeong).

First keyword "gi" means an explosive energy. Koreans are apt to vent their emotions. The etymology of the word "emotion" comes from the Latin word "emovere" which means "move out (of oneself)." If reason as a modern invention is a static and hierarchical thing, emotion is a movement or a communication with the world. Emotion can be very powerful, dynamic and competitive, when it is expressed in the arena of popular culture. Although Korea, Japan and China are supposed to be together under the "similar" cultural zone, Korea is the only Asian country to "wail loudly" (even beating their breasts) at the funeral. For example, Korean "noraebang (karaoke)" culture $^{41}$ well shows this emotional "explosion" culture of Koreans.

Second keyword "heung" can be translated as fun or joy. Koreans are fun-loving and fun-seeking people. No one like being bored, but in Korean language, "no fun" is often used to scare people. Third keyword "jeong" is a compassion which literally means "to suffer together" or affection. This jeong affects a lot of Korean business culture. For example, "Orion Choco-pie Affection (jeong)"has been loved by people from many parts of the world. ${ }^{42}$ This is thanks to Orion Choco-pie's affection marketing that has attracted attention as a successful marketing case. It is not too much to say: "I know what you really saying, even when you don't say it. Choco-pie is jeong! (a catchphrase of Choco-pie)" Aside from three Korean cultural DNAs, Koreans also have peculiarly sorrowful sentiment (han) derived from suppressed feelings. It is said that Koreans resolve their han (deep sorrow) through their heung (fun and joy), such as dynamic nongak (traditional Korean music performed by farmers) and cheerful ganggangsullae (traditional Korean circle dance). ${ }^{43}$

On the other hand, we can enumerate, as one of success equations of hallyu, the "education fever." We cannot say K-pop without education. The planning system of training young stars is well organized in Korea. In point of fact, we shouldn't ignore the achievement needs of Korean idols, being chosen through fiercely competitive auditions. The synergy effects of ICT (information and communications technology) are also important. The success of hallyu is based on Korean knowledge management capability: namely, the combination of IT and CT.Hallyu is a digital phenomenon on the consumer side. Behind the popularity of hallyu, there is an active on-line exchange/knowledge share of digital cultural contents among new Asian generations.

Finally, the success of hallyu as a cultural "hybridity" represents the light side of a Kitsch empire. Hallyu is not entirely composed of Korean things, but of glocal (global and local) ones to suita global consumer's taste, through hybridization technology. Hallyu is mingled with Korean gi (energy), heung (fun), jeong (affection), education, ICT and hybridity, etc. Thus, hallyu is not an unexpected product, but a sustainable phenomenon. Hallyu is spotlighted as a dominant "cultural gene" which has replaced J-pop and Hong Kong's Noire and martial arts movies in Asia through the competitive advantages. Unlike previous cynical views of hallyu as "bubble" phenomenon, hallyu has a great ripple effect, enough to instill a sense of civic pride and patriotism in the "mentalités" (collective mentality) of Koreans suffered from a cultural inferiority complex since the Japanese colonial period. There is no blue ocean in the world. As soon as we shout "Blue Ocean," it turns to Red Ocean. However, there will be always a blue ocean in cultural domain. Nobody can imitate Harry Porter. The keyword of cultural industry is "originality"; therefore, the best is not enough, but the "only" can survive.

\footnotetext{
${ }^{41}$ The Korean word "noraebang" literally translates to song(norae) room(bang). A noraebang is a karaoke box where people go to sing.

${ }_{42}$ Choco-pie, which first came out in 1974, has sold 9 billion pieces in Korea, reaching cumulative sales of more than eight billions euros to date

${ }^{43}$ Ganggangsullae is a 5,000year-old Korean dance that was first used to bring about a bountiful harvest and has developed into a cultural symbol for Korea. It incorporates singing, dancing, and playing and is exclusively performed by women. 